\title{
Acculturation Process of Arab-Muslim Immigrants in the United States
}

\author{
Jamil Al Wekhian ${ }^{1}$ \\ ${ }^{1}$ Department of Peace Studies, University of Missouri-Columbia, USA \\ Correspondence: Jamil Al Wekhian, Department of Peace Studies, University of Missouri-Columbia, USA. \\ E-mail: alwekhianj@missouri.edu
}

Received: October 14, 2015 Accepted: October 21, 2015 Online Published: November 2, 2015

doi:10.5539/ach.v8n1p89

URL: http://dx.doi.org/10.5539/ach.v8n1p89

\begin{abstract}
While globalization has made this world smaller, interdependent, and heterogeneous, clashes among different cultures became inevitable. Immigrants leave their home country for many reasons, by choice or necessity. The U.S. is considered one of the countries that enjoys its cultural diversity. In the case of Arab-Muslim immigrants, they came to the U.S. either seeking a better life, or fleeing prosecution. They come from completely different culture, language, and religion. This move makes them prone to experience one or more challenges: assimilation, integration, separation, or marginalization. Since assimilation is very hard to achieve, integration is the ideal choice for which scholars aspier. This paper investigates the acculturation process of Arab-Muslim immigrants in the U.S. Results showed a variety of potential barriers exist hindering Arab-Muslim immigrants from successful integration into the United States society. Cultural and religious differences, distinctions in moral and ethical values, perception of gender relations, demonization of the Arab population in mass media, and discrimination are the major factors causing the overall struggles of the acculturation process.
\end{abstract}

Keywords: acculturation, culture, immigrants, Arab, Muslim, and United States, Middle East

\section{Introduction: Background Information}

In the last several decades, population migration increased greatly in many parts of the world, including the United States. This means that a great number of people in the world, by choice or necessity, have moved to another state despite their country of origin. Such movements are explained by a variety of reasons, but scholars especially underline the economic security or globalization processes. However, in spite of the causes, it has to be noted that immigration is a difficult and complicated process, especially if an individual immigrates to a country with a different culture, language, and overall values. Despite the rapid processes of globalization where cultural differences are blurring, it is impossible to claim that the distinctions are totally gone. Westernization tends to penetrate even the deepest corners of the world, but there are still a wide variety of diversities between and within different nations (Zemore, 2007).

Western and non-Western cultures contain distinctions between each other that are embodied in values, ethical standards, languages, moral principles, methods of approaching problems, behavior, traditions, and customs. Certainly, even the division between Western and non-Western, or Western and Eastern cultures is controversial, and artificial (Said, 2003). As Said argued in Orientalism Reconsidered, the line that separates Occident from Orient is not one that is present by nature (1985). Said states, "there could be no Orientalism without, on one hand, the Orientalists, and on the other, the Orientals." Similarly, Spivak (1988) emphasizes that much of Western academic thinking has underlying motivations and biases. She questions how non-Western society can be studied without considering colonial implications of defining the "other" "over there." This speaks to the point of Western scholars documenting non-Western culture in academia, implying they are the most qualified and educated to speak on the subject. Or, how the media and Western culture label minority groups within society to meet their own needs, referencing portions of religious script, taken out of context, or only putting images of those who vilify a religion rather than represent it. It is difficult these days to use the label of "Arab" or "Muslim" without thinking of the term terrorists or Islamic extremists. Even those in the public spectrum who avoid using such labels are criticized for not augmenting the media-supported link between Islam and terrorism. Nevertheless, in this study the terms Western and non-Western will be utilized for the sake of simplicity.

The list of differences among cultures can be long if analyzing the history of both regions and the development of non-Western and Western cultures. In reviewing Middle Eastern culture, it is easy to find even more distinctive patterns that can be characterized as different, and even at times the opposite to Western values (Chen, 
2012). One question that arises from the study of Orientals is the motivation for such an endeavor. While Lewis argues that this quest is "motivated by pure curiosity," Said argues that there are multiple underlying biases that motivate such a quest (1985). Nonetheless, differences among those from different backgrounds do exist, but they don't exist by nature as essentialism theory would have one believe, through their "essence," but, rather, they are relative (Tan, 2014).

Such diversity usually leads to clashes and conflicts at all levels, as individuals from each culture perceive reality in a different way, drawing distinctive conclusions based on their own experiences. In light of current events, it is reasonable to argue that the relationship between the Middle East and the West is not in the best condition. Especially hostile relations between these regions can be observed due to multiple events preceding the present situation.

The United States is a country of unique composition. Inhabited by a great variety of ethnicities, races, and nationalities, the United States has become a diverse container of people from all corners of the world. Millar and Shamshad (2013) emphasized that "the number of immigrants in the United States continues to rise, increasing from 28 million foreign-born individuals in 2000 to approximately 39 million foreign-born individuals in 2009" (p. 1). Constant diversification makes the United States a special place where different cultures are blending, enriching each other with special features and unique experience.

At the same time, despite the constant attempts to blur the barriers between different cultural clusters, conflicts between people erupt on a daily basis (Lerner, 1986). The reasons for the conflict can be different, but bearing in mind the cultural diversity, it is easy to assume that a distinctive global outlook is one of the main causes. Taking into consideration the potential differences between United States and Middle Eastern culture, it is easy to assume that immigrants from the Middle East experience the biggest difficulties during the process of acculturation.

It must be stated that acculturation of some kind is the inevitable process in the case of immigration, despite the cultural differences between the cultures. Schwarz et al. (2006) gave the following definition of acculturation, "in the most general terms, acculturation can be defined as the process of cultural change and adaptation that occurs when individuals from different cultures come into contact" (p. 2). Each immigrant undergoes acculturation at different levels, like adaptation to ideas and values and retention of norms existing in the culture of the country where he or she came from. It was also revealed that the identity of an immigrant experiences particular alterations as well, at the level of both cultural and personal identities (Chen, 2012). In the case of Northern and Western Europeans, the assimilation process to American culture may be easier. Many of these immigrants are similar to the dominant United States culture in their racial and religious characteristics and actually share many cultural norms (Alba, 1990). These immigrants were often more skilled and educated than some other immigrant groups, allowing them to bring more money to the United States and secure a more stable beginning, which contributed to the lower degree of rejection (Alba, 1990). However, for the immigrants who came from countries with stronger cultural differences, they often undergo more difficult processes of acculturation. In this case, some Middle Eastern or Arab immigrants can serve as an excellent example.

\section{Roots of Acculturation}

Martin (2005) traced the roots of acculturation to 1880s anthropology literature. It was developed to enhance understanding of the change that occurs when "two or more autonomous cultures interact with each other" (Martin, 2005, p. 72). While some scholars, such as Bisin and Verdier (2000), argue that the assimilation theory fails, and that individuals strive to maintain their culture, others such as Berry (1980), believe there are multiple ways for individuals to go through the acculturation process. For example, some individuals assimilate, and specifically don't want to maintain their native cultural identity; instead they become absorbed into the host society (Redfield, Linton, \& Herskovis, 1936). The other extreme is individuals that separate, placing a value on holding on to their original culture while at the same time avoiding interaction with others (Berry, 1980). Others integrate, trying to maintain their own culture through interacting with other groups (Berry \& Kalin, 1995). Finally, there are those who marginalize, who avoid social interaction with others (to avoid exclusion or discrimination) and have little interest or possibility in maintaining their heritage (because of enforced cultural loss) (Berry, 1997). Redfield, Linton, and Herskovits (1936) stated "acculturation comprehends those phenomena which result when groups of individuals having different cultures come into continuous first-hand contact with subsequent changes in the original cultural patterns of either or both groups" (p. 149).

Arabs have been immigrating to the United States since the 1800s (Abu-Laban \& Suleiman, 1989). However, the majority of Arabs immigrated after the 1960s (McCarus, 1994). This is due to the Immigration and Naturalization Act of 1965, which abolished the national quota system that structured the United States 
immigration policy since the 1920s, replacing it with a preference system focusing on immigrant skills and family relationships with United States citizens and/or residents (Keely, 1971). Ammar (2000) argued that Arab immigrants (or Americans of Arab descent) are divided into two categories: Christians who held the majority of the early waves of immigration in the 1800s and Muslims who made up the bulk of Arabs in the second wave after the 1960s.

Little research has focused on the second wave of Arab immigrants in the United States. El-Sayed (1986), however, found a positive relationship between the length of residence and the acculturation process for Arab immigrants, indicating that the longer their residency, the more they are assimilated to United States culture. Nevertheless, differences in language, ethnicity, culture, and religious practice between generations of Arab-Muslim immigrants are exhibited in the United States workplace. Another study by Amor (2006) revealed interesting results that Arab-Muslim immigrants in the United States tended to design their homes in the United States in such a way that it kept them attached to their origin. The interior furniture and accents were mostly imported from their country of origin. The way they divided their rooms was also influenced by their root culture. In essence, the Arab-Muslim immigrants transformed their physical culture to compensate for alienation they experienced in United States culture.

\section{Overview of Acculturation Process Specific to Arab-Muslim Immigrants}

Before digging deeper into the acculturation process of Arab immigrants, it is important to note that the United States has been a country of immigrants since its birth. While talking about the existence of dominant culture, it is crucial to remember that in the United States prevailing culture consists of different blocks representing various origin nations. Therefore, it is rather difficult to claim that the dominant culture in the United States is homogeneous, it does, however, have shared vision, values, and norms characteristic for the majority of the American citizens despite their cultural identity. Certainly immigrants to the United States experience some changes in their lives upon arriving to the United States, and some face a complete culture shock. The acculturation process differs from one immigrant to the next. In some cases, immigrants move to areas within the new host country where they already have previous acquaintances. This explains the mini-niches in the United States of people of various cultures, such as the Somali population in Minnesota, Italians in New York, Bosnians in St. Louis, Mexicans in Texas and California, and Arabs in Detroit. In these cases, the culture shock appreciated by immigrants may be mitigated, because they are in a more familiar environment compared to an immigrant who moves to a host community in which there are no other similar minorities. Nevertheless, for immigrants the process of acculturation is difficult and ongoing where the level of difficulty depends on several issues. Several studies found that the duration of stay within a country, the range of differences between the cultures, age of immigrants, intermarriage, and discrimination play the most important role in immigrants' acculturation despite the country of origin (Eylem Gevrek, Gevrek, \& Gupta 2013).

It is important to explore the specificity of recent and current Arab immigration to the United States. While past researchers found that the majority of the Arab immigrants coming to the United States were Christian (Ayoub, 1989, p. 28), later studies revealed that around 75 percent of modern Arab immigrants practice Islam (Camarota, 2002 , p. 320). Such differences can be associated with an overall increase of popularity of the fundamental movements in the Middle Eastern countries due to reasons that still remain unknown to scholars (Duschinsky, 2012, p. 22). Nobles and Sciarra (2000) discussed the roots of each wave of Arab immigrants. The first wave, which took place in the late $19^{\text {th }}$ century consisted mostly of Arab Christian males from Syria and Lebanon who intended to stay in the United States for a short time to earn sufficient income to improve the quality of life for their families overseas. The second wave, described by Nobles and Sciarra, included more Muslims, many of whom were Palestinians, Syrians, and Iraqis escaping political conflict as well as those Palestinians displaced by the establishment of Israel. Finally, the third wave beginning in the mid-1960s consisted of many professionals and entrepreneurs who fled unrest and wars in the Middle East (2000).

As to the Arab immigrants, Faragallah et al. (1997) stated that "length of residence in the United States has a positive relation with the acculturation process for Arab immigrants" (183). In general, the duration of exposure to a different culture plays a dominant role among the other factors not only among Arab immigrants, but also those who came from other regions showed the same correlation as well (Faragallah , 1997). It makes sense, as the more an individual is exposed to a particular culture, the more possibilities that he or she will obtain the same values, interests or vision of the world as the host culture contains. At the same time, it was argued that Arab immigrants are the most difficult to assimilate to the dominant culture. While conducting research, Khalid et al. (1997) found out that "the majority of immigrants questioned in the survey revealed that most were more inclined to retain their original national culture for their private and/or social lives than to adopt the United States 
national culture" (p. 217). Such results make it possible to investigate what the reasons are for such rejection of the host culture.

One of the central reasons and perhaps the most influential one is the religious differences between the Arab immigrants and the United States population. The majority of Arab immigrants follow Islam, while the United States dominant religion is, despite the diversity, Christianity. However, I argue that religious differences play less of a significant role than the great quantity of conflicts that can be found in history. The first known armed clash between Christians and Muslims dates back to 1096, the First Crusade, that was inspired by religious as well as economic differences (Ayoub, 1989, p. 30). After that time, world history experienced a substantial number of armed conflicts between the representatives of these religions, escalating and culminating in the division and colonization of the Arab world by the great Western powers after World War I. Therefore, it has to be noted that some hostility existing between these cultures is understandable. Taking into account the events happening in the present day, it is easy to see the reason why some Muslims and Christians find it difficult to co-exist peacefully in the current conditions. It should also be noted, however, that some scholars naturalize the conflicts between Christianity and Islam. This, however, is not accurate (Karabell, 2007). For most of history in fact, Muslims and Christians have lived as neighbors without major conflict (Mamdani, 2002).

At the same time, the level of opposition to the process of acculturation seems to be different among Arab immigrants, if taking into consideration such variables as religion. Ibrahim and Cass (2011) revealed that the success in acculturation process of Arab immigrants depends on the level to which they stick to the religious traditions and the character of religion as well (p. 388). Islam, as with other world religions, contains different interior movements distinctive from each other in beliefs, traditions, norms, and values. Such differences, according to Ibrahim and Cass (2011), play an immense role in the future process of acculturation, where more radical Islamic views hinder the process of acculturation (p. 389).

Despite religion, which may be the primary cause of slower acculturation processes, age was revealed as a prominent factor influencing the process of acculturation as well. It was observed that the younger the immigrants are, the easier the process of acculturation they are undergoing. This finding is important, as children tend to be more flexible on several levels, including linguistic and perceptual (Berry et al., 2006, p. 330). In addition, depending on the age of a child, easier acculturation stems from the fact that children were exposed to the culture of their country of origin less time than were the adults. However, some scholars argue that the level of acculturation among children depends on family traditions as well (Ibrahim \& Cass, 2011, p. 388). As children depend on older family members, their acculturation process can be influenced by them, and in the case of the practicing of more radical traditions, the acculturation will generally be more difficult.

One additional factor positively influencing acculturation among Arab immigrants is the level of satisfaction with life in the United States. Aprahamian et al. (2011) revealed that the extent to which an Arab family is satisfied with life in the country where they immigrated is directly proportional to their rates of acculturation (p. 82). Such correlation refers to the hypothesis that many people immigrating to the United States are not satisfied with life in their country of origin. Stout (2008) provides an excellent analysis on the reasons why immigrants come to the United States. Financial incentives or aspirations are not the only motivating factors that lead immigrants to leave their native country. Sometimes people immigrate to the United States to flee oppression and brutal killing (Stout, 2008). Take for example, the recent influx of Syrians, Iraqis, and Libyans who left their native countries due to the ongoing lack of safety from war. Alfred (2001) suggested "the basic reason why immigrants come to America is the gap between the life aspirations and expectations and the means to fulfill them in the sending country" (p. 3). At the same time, economic and social factors can play the most important role in the level of satisfaction, which at the beginning of life in the United States can often be quite difficult for immigrants. It has to be noted that satisfaction with life at the initial stages of acculturation can be very difficult, as immigrants undergo a difficult process where they struggle to live in the conditions of a broadly different culture, language, values, and norms of behavior. Ultimately, the reasons for immigration vary, which plays a role in the acculturation process of immigrants.

Intermarriage is one of the factors influencing the acculturation process of Arab immigrants. According to Kulczycki and Arun (2002), "the extent to which ethnic intermarriage occurs is widely accepted as an important indicator of assimilation and identification" (202). Arab-Muslim immigrants are not excluded from this rule. However, as scholars insist, intermarriages among Arab-Muslim men happen more frequently than among Arab women due to their cultural traditions and religious beliefs. "Four out of five (79\%) Arab-Muslim men and more than three out of five (60\%) Arab-Muslim women had non-Arab spouses" (Kulczycki \& Arun, 2002, p. 208). Intermarriage was revealed as a positive factor in the process of acculturation, as it facilitates the interchange between the cultures, smoothing the corners. However, as it was revealed, some Arab husbands insist on change 
of religion from their wife, and continue to live within the traditional family mode characteristic to their Arab culture. Perhaps this is rooted in Islamic regulations that prohibit women from marrying non-Muslim men but allow Muslim men to marry women who were of the book (Christian, Jewish, or Muslim) (Ali, 2010). The mentality behind this is that the father should be Muslim so that his children may continue the legacy of Islam (Ali, 2010).

While discussing the factors positively influencing on the acculturation process, it is important to emphasize the conditions that have directly opposite effects. Researchers found that discrimination is the main negative factor preventing the Arab immigrants from successful acculturation (Willems, 2012; Shaheen, 1984). He emphasized the significance of this factor in the process of successful acculturation among Arab immigrants, claiming that they became the targets of racial discrimination due to racial patterns existing in the United States. According to the author, Arab immigrants have diverse religious and cultural beliefs that have been substituted in the popular culture by images of terrorism and extreme violence (Willems, 2012, p. 2; Shaheen, 1984).

This factor plays a negative role in the process of acculturation due to its ability to influence the quality of life of immigrants as well as their mental state. However, at a much broader level, the entire acculturation process itself can be a huge source of stress to immigrants. Khalid et al. (2007) state that "when people come into contact with a new culture, differences in the language, physical, and psychological dimensions from their original culture cause them to experience acculturative stress" (218). At the same time, discrimination often remains one of the central factors causing stress among Arab immigrants. Ramdhonee and Bhowon (2012) showed the same process to be ongoing among the majority of immigrants, despite their degree of acculturation (p. 126).

There are several studies proving that discrimination can cause serious mental strain and even impairment among Arab immigrants (Aprahamian et al., 2011; Willems, 2012; Jadalla and Lee, 2012). Such assumptions are relevant if taking into account that the image of Arabs is rather negative in the United States. Experiencing constant hostility, the immigrants tend to exclude themselves from other communities except their own. It was emphasized by Jadalla and Lee (2012) that Arab immigrants experience discrimination in the job market, in public places, in the workplace, and in daily life overall (p. 164). Such exposure of ongoing discrimination frequently leads to serious mental health problems, like depression, anxiety, and trauma. Discrimination is one of the reasons why Arab immigrants stay within their own community, not making the attempts to interact with representatives of other communities (Aprahamian et al., 2011).

While discrimination against Arabs and Muslims in the post 9/11 era certainly intensified, these events did not mark the birth of discrimination and stereotypes against Arabs and Muslims (Mamdani, 2002). Aprahamian et al. (2011) underlined that Arab immigrants feel themselves inferior compared to other citizens, due to constant discrimination and the stereotypical image of their ethnicity in the eyes of the United States population (p. 93). The acculturation process can become nearly impossible if the dominant culture rejects the immigrants of a particular nationality or ethnicity. While some still harbor the belief that the United States has a unique composition as a diverse country that prohibits discrimination against anyone, it also should be noted that the hostility against Arab immigrants is more tolerated than toward almost any other minorities (Camarota, 2002).

The situation intensified after the 9/11 attack and the following war on terror proclaimed by the United States that predisposed the Iraq War and several armed conflicts of the United States military within the Middle Eastern and Islamic countries. Nassar-McMillan et al. (2011) argued that due to the constant conflicts between the United States and the Middle East, "some Arab immigrants become active in social justice initiatives, others may become embittered and further disenfranchised, while still others may vacillate due to situational criteria" (p. 38). The relationship between the Arab-Muslim immigrants and the United States citizens sharpened significantly and stays critical nowadays due to such episodes as the Boston Marathon Bombing (The Associated Press). Such intensification of Arab and/or Muslim stereotypes or misconceptions makes it even more difficult for Arab-Muslim immigrants to acculturate in United States host culture (Nassar-McMillan et al., 2011 p. 39).

At the same time, some researchers emphasized that despite the negative attitude of the United States citizens to their culture especially after the events listed earlier, Arabs tend to immigrate to the United States anyway. "Interest in coming to America remains very strong in the Middle East even after September 11" (Camarota, 2002 , p. 315). These interests could be due to bad economic situations, ongoing armed conflicts, or political reasons in their native country, as a large proportion of Arab immigrants are also refugees (Haboush, 2007). In addition, Camarota drew attention to the fact that a great number of Arab immigrants tend to be highly-trained specialists and well-educated individuals who usually seek better employment and economic stability, which they cannot find in their motherland (p. 318). 
Nevertheless, analyzing the factors influencing the acculturation process among Arab immigrants, it is possible to determine the primary root of the difficulties preventing them from assimilating into United States culture more successfully. While reviewing all causes, the differences in religious beliefs and traditions are the central barriers of mutual understanding between the American citizens and Arab immigrants. It is possible to assume that some quantity of differences stem from stereotypical perceptions of Arabs and the Middle East in general; though the distinctions between the Western and Middle Eastern countries do exist at different levels, and are, therefore, also real factors in social dynamics.

\section{Traditional Differences between Arab Immigrants and Western Civilization}

This section focuses on the complex differences between Arab culture of immigrants and United States hegemonic culture. This comparison is vital because it plays a significant role in the overall acculturation process of Arab Muslim immigrants. According to the United States Religious Landscape Survey conducted in 2012, the majority of the United States citizens who characterized themselves as religious claimed to be Christian (72\%), while, for example, the inhabitants practicing Islam were in a minority $(0.6 \%)$. Such radical difference makes it possible to claim that Christianity in America is the dominant religious tradition (U.S. Religious Landscape Survey, 2012).

While comparing religious beliefs, one of the primary distinctions that divide Muslims and Christians is the traditionalism of Islam. While comparing the Middle Eastern and Western countries, it is possible to surmise that religion in general plays a less significant role in the West. In the United States, religion is a generally personal choice of the individual, but in mainstream United States culture, it doesn't necessarily influence the daily lives of all members of society. In the majority of the Middle Eastern countries, Islam plays a more prominent role, influencing every aspect of the lives of its citizens and even newcomers (Kattan, 2014).

Traditions of Arab immigrants who follow Islam are rooted in their religion, which influences their everyday and personal life, in some cases including food and clothes. There is a paucity of such traditions in Western culture, as people often choose such things according to their interests and needs. Providing an example of such traditions, Islam does not permit its followers to eat pork. Women tend to wear special clothes covering their figure, head, and, in some cases, even their faces (Mishra, 2007, p. 5). In addition, followers of Islam have to pray five times a day despite the fact that this can be a difficult routine in the conditions of Western cities (Bankston \& Hidalgo, 2006, p. 29). Certainly all Muslims do not necessarily avoid pork, wear the expected modest clothing, or pray five times a day. However, Muslims are more likely to have a greater level of religiosity than their Christian or Jewish counterparts (Bankston \& Hidalgo, 2006; Wilson \& Power, 2004)

Nevertheless, while analyzing the differences in traditions and religions, it should be noted that the most vivid distinction among all may be the social construction of gender roles and customs by both cultures. In this aspect, the views are radically opposite, as the Middle East in general is highly masculine culture where women are not perceived as equal to men (Hakim-Larson, 2007, p. 315). Such attitude to women can be observed at different levels in the countries practicing Islam, especially of fundamentalist nature, like Saudi Arabia, Pakistan, and Iran.

However, even in the countries where radical views are followed only by minorities, women do not have equal rights with men. The type of clothes, the ability to go out, drive a car, doing a job, or even speaking to individuals of the opposite gender is regulated by the respect of the Islamic teachings (Cook-Masaud \& Wiggins, 2011, p. 248). This is only a brief overview of the Islamic view towards women. On the contrary, in the United States, equal rights in general are the central ideas of the cultural life, with some exceptions in the smaller cities and rural communities in the South and border states. Therefore, such traditions practiced by Arab immigrants contradict United States culture and its legislation.

In addition, Arab immigrants usually complain that it is rather difficult to preserve family traditional values in the conditions of the United States today due to various reasons. According to the traditions existing within the Middle East, the family is a sacred compound of the society, as are the family ties. In comparison to United States culture, it is possible to generalize that while family values certainly do exist within the culture, their influence is less significant, for example, in professional life, or in personal interests and use of space.

While Western culture is dominated by ideas of individualism, the Middle Eastern world can be characterized more as collectivist. Yet, it is possible to claim that family values in both cultures play very different roles. Emphasizing this point, Abu Baker (1999) revealed that for "Arab people who live within collective societies, socialization process leaves very little for individual decisions" (p. 953). Thus, it is possible to assume that the acculturation process targeting an individual despite the collective will lead to negative consequences. Being absolutely patriarchic, an Arab family has the right to decide the destiny of their children and does not accept the 
concept of divorce (Itzhaky \& Ribner, 1999, p. 135). An average United States family has different values, which can further result in misunderstanding within the society.

The moral values of Arab immigrants tend to be very different from the American norms as well. The most vivid distinction can be observed in the inter-gender relations, where women and men are not allowed to engage in a pre-marital relationship, or in some cases even to be alone in a room with each other (Boosahda, 2003, p. 53). Taking into account open-mindedness of the United States citizens in such questions and popularity of mass media in the country, it is easy to assume that Arab immigrants tend to feel uncomfortable in such conditions. Overall, it is possible to assume that the cultural traditions usually practiced by Arab immigrants differ from the norms and values existing within Western culture and in the United States in particular.

Taking into account the traditions characteristic of Arab immigrants, it is plausible to conceptualize that their acculturation process contains a substantial number of cultural barriers that are difficult to overcome at once. The results of the investigation performed by Barry (2005) and Barry et al. (2000) showed that the acculturation process of Arab immigrants "was not associated with overall ethnic identity investment, religious-family values, or sense of belonging" (p. 182; p. 141). In general, the researchers argued that the process of acculturation and integration into United States society was accompanied by total refusal of the traditional values existing within Middle Eastern culture.

Such findings can be perceived as the negative outcome of the acculturation process, as the participants in the study lost their cultural identity. From the other point of view, such exploration revealed that one reason for the successful acculturation of the Arab immigrants is the loss of cultural identity. This conclusion leads to the question of whether traditional Middle Eastern culture can seamlessly co-exist within the dominant United States culture, especially in the case of first generation Arab-Muslim immigrants to the United States.

\section{Negative Aftermaths of a Difficult Acculturation Process}

The consequences of a difficult experience with acculturation for some immigrants can lead to unwanted results. As was mentioned earlier, due to the potential challenges, some Arab immigrants may even experience health disparities due to the obstacles of acculturation. Interestingly, Brown et al. (2003) showed that the lack of acculturation for some Arab immigrants could increase the risk for diabetes. The primary factors contributing to the development of diabetes were traditional Arab food, older age, and less activity among the immigrants (Brown et al., 2003, p. 15). Other scholars also revealed negative health consequences among the Arab immigrant populations due to their inability to acculturate faster. Hattar-Pollara and Meleis (2005) argued that some of the participants in their study underwent serious distress while trying to create similar conditions of living compared to their motherland within the settings of the United States; and when constantly failing to reach their goal, the examinees experienced severe stress.

While mentioning that the process of acculturation can be particularly stressful, the resistance to acculturation can be even more destructive for some immigrants. Taking into account the fact that some Arab immigrants experience difficulties in the ability to accept United States culture, their levels of distress and constant medical problems could lead to even more serious impairments, in their mental state, as well as in the overall health quality. At the same time, it is crucial to acknowledge that psychological distress as the symptom of failed acculturation process was found among other ethnicities emigrating to the United States.

Benner and Kim (2010) found that Chinese immigrants sometimes experience similar health struggles as their Arab counterparts (p. 2). Other scholars came to similar conclusions. Greenberger and Chen (1996) suggest that high levels of stress were characteristic for Asian immigrants as well (p. 714). Ultimately, high levels of distress among immigrants exacerbate existing challenges in the acculturation process, and in the ability to integrate successfully into the community.

Such levels of stress and ongoing process of acculturation are frequently the cause of conflicts within the family. As mentioned above, children tend to experience the acculturation process far more easily than adults. Such difference in the ability to acculturate can be the reason of conflicts in the family between the children and parents of immigrants (Kim, 2011; Farver et al., 2002). Kim and Wolpin (2008) agreed with this conclusion, as the adolescents from the immigrated families tend to undergo the process of acculturation quicker and adopt new culture faster than their parents (p. 115). In another study investigating the acculturation process of Asian immigrants, Chung (2001) argued that "there are patterned variations in intergenerational tensions over expectations regarding family interactions, educational and career concerns, and dating and marriage issues" ( $\mathrm{p}$. 382). Chung also argued that the clashes between first generation Asian immigrants tended to occur more frequently with their daughters, but that the clashes among immigrant families were reduced as the parents became more aware of United States culture. Farver (2002) also conducted a study on Asian/Indian families and 
argued that the stress level in the acculturation process was positively correlated with the difference between the native and host culture. Farver also argued that the less integrated to United States culture the parents (first degree immigrants) were, the greater the extent of psychological problems within their family. Such differences in acculturation, in some cases, can lead to difficulties in the relationship between the parents and their children and the further breaking of ties with family members and the cultural identity.

While noticing that the loss of cultural identity can be the price of acculturation, it is also important to emphasize that this is a negative aftermath of acculturation overall. Such a result is almost inevitable and in some cases can be omitted if some of the traditional values can exist within the dominant culture. Berry (2008) stated that the process of ongoing globalization and the recent tendencies of migrations of population lead to the diminishing role of cultural identity within society, as it tends to be global and common to everyone (p. 329). It is a frustrating process; though, as the results showed, the loss of cultural identity was the aftermath of Arab immigrants' acculturation in the majority of cases. Despite Berry's statements, many Arab immigrant families continue to move to the United States and a large majority of them strive to maintain their native culture and religion. While the acculturation process may lead to incorporation of some components of American culture, this is not to say that a global culture for these immigrants overwhelms that of their original roots.

As Bisin and Verdier argued in "Beyond the Melting Pot," the theory of assimilation has not been a certain phenomenon (2000). Herberg (1960) provided the example of religious traditions of Catholic, Protestant, and Jewish immigrants who strived to maintain their religious beliefs to distinguish from each other. Bison and Verdier also focused on the generational differences in assimilation when comparing first and second-generation immigrants, and how parents tried to influence their children's characteristics through "direct socialization," which sometimes conflicted with the indirect socialization of society on second generation immigrant. In fact, many immigrants purposefully strive to maintain their own identity and try actually to avoid assimilation to their host culture. This becomes more interesting when considering the children of immigrants, the generation who was exposed to their parents' (and arguably their) native culture, and that of the United States, the country in which they grew up.

\section{Conclusion}

While analyzing the process of acculturation of Arab immigrants in the United States, I found that there are a variety of potential barriers hindering Arab-Muslim immigrants from successful integration into the United States society. Cultural and religious differences, distinctions in moral and ethical values, perception of gender relations, demonization of the Arab population in mass media, and discrimination are the major factors causing the overall struggles of the acculturation process. The difficulty of some Arab immigrants to acculturate successfully sometimes rooted in their beliefs and eagerness to maintain the same conditions of living within the country where the majority of such beliefs are not widely accepted. As a result, Arab-Muslim immigrants tend to stay within their ethnic and national community, which makes the process of acculturation even more complicated.

\section{References}

Abu Baker, K. (1999). Acculturation and reacculturation influences: Multilayer contexts in therapy. Clinical Psychology Review, 19(8), 951-968. http://dx.doi.org/10.1016/S0272-7358(99)00005-7

Abu-Laban, B., \& Suleiman, M. W. (Eds.). (1989). Arab Americans: Continuity and Change. Belmont, MA: Association of Arab-American University Graduates.

Alba, R. (1990). Ethnic Identity: The Transformation of White America. New Haven: Yale University Press.

Alfred, M. V. (2001). Immigrants in America: Who are they, and why do they come?. Adult Learning, 12/13(4/1), $2-5$.

Ali, K. (2010). Marriage and Slavery in Early Islam. Cambridge, Mass: Harvard University Press.

Ammar, N. H. (2000). Simplistic stereotyping and complex reality of Arab-American immigrant identity: Consequences and future strategies in policing wife battery. http://dx.doi.org/10.1080/095964100111517

Amor, C. M. (2006). Arab-American Muslims' home interiors in the U.S.: Meanings, uses and communication. Journal of Interior Design, 32, 1-16.

Aprahamian, M., et al. (2011). The relationship between acculturation and mental health of Arab Americans. Journal of Mental Health Counseling, 33(1), 80-99.

Ayoub, M. M. (1989). Roots of Muslim-Christian Conflict. Muslim World, 79(1), 25-45. http://dx.doi.org/10. 1111/j.14781913.1989.tb02833.x 
Bankston, C. L., \& Hidalgo, D. A. (2006). Respect in southeast Asian American children and adolescents: Cultural and contextual influences. New Directions for Child and Adolescent Development, 114, 25-38.

Barry, D. (2000). Foreigners in a strange land: Self-construal and ethnic identity in male Arabic immigrants. Journal of Immigrant Health, 2(3), 133-144.

Barry, D. T. (2005). Measuring acculturation among male Arab immigrants in the United States: An exploratory study. Journal of Immigrant Health, 7(3), 179-84. http://dx.doi.org/10.1007/s10903-005-3674-9

Benner, A. D., \& Kim, S. Y. (2010). Understanding Chinese American Adolescents' developmental outcomes: Insights from the family stress model. Journal of Research on Adolescence, 20(1), 1-12. http://dx.doi.org/ 10.1111/j.1532-7795.2009.00629.x

Berry, J. W. (1980). Acculturation as varieties of adaptation. In A. Padilla (Ed.), Acculturation: Theory, Models and Findings (pp. 9-25). Boulder: Westview.

Berry, J. W. (1997). Immigration, acculturation and adaptation. Applied Psychology, 46, 5-68. http://dx.doi.org/ 10.1111/j.14640597.1997.tb01087.x

Berry, J. W. (2006). Immigrant youth in cultural transition: acculturation, identity, and adaptation across national contexts. Applied Psychology: An International Review, 55(3), 303-332.

Berry, J. W. (2008). Globalization and acculturation. International Journal of Intercultural Relations, 32(4), 328-336.

Berry, J. W., \& Kalin, R. (1995). Multicultural and ethnic attitudes in Canada. Canadian Journal of Behavioural Science, 27, 310-320. http://dx.doi.org/10.1037/0008-400X.27.3.301

Bisin, A., \& Verdier, T. (2000). 'Beyond the melting pot': Cultural transmission, marriage, and the evolution of ethnic and religious traits. Quarterly Journal of Economics, 115(3), 955-988.

Boosahda, E. (2003). Arab-American Faces and Voices: The Origins of an Immigrant Community. Austin, TX: $\mathrm{U}$ of Texas.

Brown, M. B. (2003). Lack of acculturation is a risk factor for diabetes in Arab immigrants in the U.S. Diabetes Care, 26(7), 10-20. http://dx.doi.org/10.2337/diacare.26.7.2010

Camarota, S. A. (2002). Immigrants from the Middle East: A profile of the foreign-born U.S. Population from Pakistan to Morocco. The Journal of Social, Political, and Economic Studies, 27(3), 315-322.

Chen, F. Y. (2012). The impact of individualistic and collectivistic orientation on the judgment of self-presentation. European Journal of Social Psychology, 42(4), 470-481. http://dx.doi.org/10.1002/ ejsp. 1872

Cook-Masaud, C., \& Wiggins, M. A. (2011). Counseling Muslim Women: Navigating cultural and religious challenges. Counseling and Values, 55(2), 247-258. http://dx.doi.org/10.1002/j.2161-007X.2011.tb00035.x

El-sayed-Ekhouly, S., \& Buda, R. (1996). Organizational conflict: A comparative analysis of conflict styles across cultures. International Journal of Conflict Management, 7(1), 71.

Eylem Gevrek, Z., Gevrek, D., \& Gupta, S. (2013). Culture, Intermarriage, and Immigrant Women's Labor Supply. International Migration, 51(6), 146-167. http://dx.doi.org/10.1111/imig.12098

Faragallah, M. H. (1997). Acculturation of Arab-American Immigrants: An Exploratory Study. Journal of Comparative Family Studies, 28(3), 182-203.

Farver, J. M. (2002). East meets West: Ethnic identity, acculturation, and conflict in Asian Indian families. Journal of Family Psychology, 16(3), 338-350. Doi:10.1037/0893-3200.16.3.338

Greenberger, E., \& Chen, C. (1996). Perceived family relationships and depressed mood in early and late adolescence: A comparison of European and Asian Americans. Developmental Psychology, 32(4), 707-716. Doi:10.1037/00121649.32.4.707

Haboush, K. L. (2007). Working with Arab American families: Culturally competent practice for school psychologists. Psychology in the Schools, 44(2), 183-198. http://dx.doi.org/10.1002/pits.20215

Hakim-Larson, J. (2007). Counseling Arab and Chaldean American Families. Journal of Mental Health Counseling, 29(4), 301-321. 
Hattar-Pollara, M., \& Meleis, A. I. (1995). The stress of immigration and the daily lived experiences of Jordanian immigrant women in the United States. Western Journal of Nursing Research, 17(5), 521-539. http://dx.doi.org/10.1177/019394599501700505

Herberg, W. (1960). Protestant, Catholic, Jew: An essay in American religious sociology. Garden City, N.Y: Anchor Books.

Ibrahim, F. A., \& Cass D. (2011). Counseling Muslim Americans: Cultural and spiritual assessments. Journal of Counseling and Development, 89(4), 387-397.

Itzhaky, H., \& Ribner, D. S. (1999). Gender, values and the work place: Considerations for immigrant acculturation. International Social Work, 42(2), 127-138. http://dx.doi.org/10.1177/002087289904200203

Jadalla, A., \& Lee, J. (2012). The relationship between acculturation and general health of Arab Americans. Journal of Transcultural Nursing, 23(159), 159-165. http://dx.doi.org/10.1177/1043659611434058

Karabell, Z. (2007). Peace be upon you: the story of Muslim, Christian, and Jewish coexistence / Zachary Karabell. New York: Alfred A. Knopf, 2007

Kattan, A. E. (2014). Christianity in a culture marked by Islam: Facts and visions. Theological Review, 35(1/2), 140-144.

Keely, C. B. (1971). Effects of the immigration act of 1965 on selected population characteristics of immigrants to the United States. Demography, 8(2), 157-169.

Khalid, M. A. (1997). The acculturation of immigrants to U.S. organizations: The case of Muslim employees. Management Communication Quarterly, 11(2), 217-265.

Kim, E. (2011). Intergenerational acculturation conflict and Korean American parents' depression symptoms. Issues in Mental Health Nursing, 32(11), 687-695. http://dx.doi.org/10.3109/01612840.2011.597017

Kim, E., \& Wolpin, S. (2008). The Korean American family: adolescents versus parents acculturation to American culture. Journal of Cultural Diversity, 15(3), 108-116.

Kulczycki, A., \& Arun, P. L. (2002). Patterns, Determinants, and Implications of Intermarriage among Arab Americans. Journal of Marriage and Family, 64(1), 202-10. http://dx.doi.org/10.1111/j.1741-3737. 2002.00202.x

Lerner, G. (1986). The Creation of Patriarchy. New York: Oxford University Press.

Mamdani, M. (2002). Good Muslim, bad Muslim: A political perspective on culture and terrorism. American Anthropologist, (3). 766. http://dx.doi.org/10.1525/aa.2002.104.3.766

Martin, D. (2005), “Advertiser acculturation in Japan: examples from foreign actors”, Asia Pacific. Journal of Marketing and Logistics, 17(2), 71-83.

McCarus, E. (Ed.). (1994). The development of Arab-American identity. Ann Arbor, MI: The University of Michigan Press.

Millar, S., \& Shamshad, A. (2013). The process of fitting in: Generational differences in self-esteem among first, 1.5, and second-generation Egyptians in the US. The Innovation Journal, 18(1), 1-12.

Mishra, S. (2007). "Saving" Muslim women and fighting Muslim men: Analysis of representations in the New York Times. Global Media Journal, 6(11), 3-12.

Nassar-McMillan, S. C. (2011). Discrimination history, backlash fear, and ethnic identity among Arab Americans: Post 9/11 Snapshots. Journal of Multicultural Counseling and Development, 39(1), 38-49. http://dx.doi.org/10.1002/j.2161-1912.2011.tb00138.x

Nobles, A., \& Sciarra, D. (2000). Cultural determinants in the treatment of Arab American: A premier for mainstream therapies: American Journal of Orthopsychiatry, 70, 182-191. http://dx.doi.org/10.1037/ h0087734

Ramdhonee, K., \& Bhowon, U. (2012). Acculturation strategies, personality traits and acculturation stress: A study of first generation immigrants from transnational marital context. Psychology Developing Societies, 24(2), 125-143. doi: $10.1177 / 097133361202400202$

Redfield, R., Linton, R., \& Herskovits, M. (1936). Memorandum on the study of acculturation. American Anthropologist, 38, 149-152. 
Said, E. W. (2003). Orientalism / Edward W. Said; [with a new preface by the author]. New York: Vintage Books, [2003], c1994.

Schwarz, S. J. (2006). The role of identity in acculturation among immigrant people: theoretical propositions, empirical questions, and applied recommendations. Human Development, 49, 1-30. http://dx.doi.org/10.1159/000090300

Shaheen, J. G. (1984). The TV Arab / Jack G. Shaheen. Bowling Green, Ohio: Bowling Green State University Popular Press, c1984.

Spivak. G. (1988). "Can the Subaltern Speak?" In C. Nelson \& L. Grossberg (Eds.), Marxism and the Interpretation of Culture (pp. 271-313). Urbana: $\mathrm{U}$ of Illinois.

Stout, R. J. (2008). Why immigrants come to America: Braceros, Indocumentados, and the Migra. Westport, CT: Praeger.

Tan, K. S. (2014). Becoming an Aikidoka: Acculturation and essentialism in the practice of Aikido. Revista De Artes Marciales Asiaticas, 9(2), 130-151.

Willems, E. A. (2012). Discrimination and Acculturation among Arab Muslim Immigrants in the U.S. Order No. 3518522 (pp. 1-224). Alliant International University.

Wilson, R., \& Power, M. R. (2004). Conflict resolution styles among Australian Christians and Muslims. Humanities \& Social Sciences papers, 76.

Zemore, S. E. (2007). Acculturation and alcohol among Latino adults in the United States: A comprehensive review. Alcoholism: Clinical and Experimental Research, 31(12), 1968-1990. http://dx.doi.org/10.1111/j. 1530-0277.2007.00532.x

\section{Copyrights}

Copyright for this article is retained by the author(s), with first publication rights granted to the journal.

This is an open-access article distributed under the terms and conditions of the Creative Commons Attribution license (http://creativecommons.org/licenses/by/3.0/). 